\title{
PENGEMBANGAN BUKU DIGITAL KIMIA PADA MATERI TITRASI ASAM BASA BERBASIS INKUIRI
}

\author{
Petri Priyatni 1 *, M. Rusdi ${ }^{2}$, Muhammad Haris Effendi-Hasibuan ${ }^{2}$
}

1 Mahasiswa Program Magister Pendidikan Kimia Universitas Jambi

2 Staf Pengajar Program Magister Pendidikan Kimia Universitas Jambi

\begin{tabular}{l}
\multicolumn{1}{c}{ Informasi Artikel } \\
\hline Sejarah Artikel: \\
Diterima: $22-03-2020$ \\
Disetujui : 15-07-2020 \\
Dipublikasikan: 20-07-2020 \\
\hline Keywords: \\
Learning media, \\
digital chemistry books, \\
inquiry, \\
ADDIE model \\
\hline
\end{tabular}

\author{
A b s t r a k
}

Analisis keperluan guru dan peserta didik menyatakan bahwa pembelajaran membutuhkan bahan ajar yang memanfaatkan multimedia sebagai media pembelajaran yang dapat diakses di handphone (HP) dan laptop. Penelitian ini bertujuan untuk mengembangkan media pembelajaran berupa Buku Digital Kimia pada materi titrasi asam basa berbasis inkuiri. Jenis penelitian ini adalah penelitian Research and Development dengan menggunakan model ADDIE. Subyek dalam penelitian ini yaitu guru kimia dan peserta didik kelas XI Mipa di SMA Plus N 2 Banyuasin III. Instrumen yang digunakan untuk mengumpulkan data berupa angket, wawancara, dan daily log. Dari hasil validasi media, materi dan desain pembelajaran menyatakan bahwa buku digital kimia ini layak untuk digunakan dalam pembelajaran pada materi titrasi asam basa. Hasil penilaian dari dua guru kimia terhadap buku digital dinyatakan sangat baik dengan uji kappa didapat nilai 0,814. Pada uji coba satu-satu mendapat kelayakan $86,67 \%$ dan pada uji coba kelompok kecil mendapat kelayakan 95\%. Buku digital kimia pada materi titrasi asam basa berbasis inkuiri layak digunakan untuk pembelajaran kimia dan diharapkan dapat diterapkan dalam pembelajaran untuk meningkatkan kemampuan berfikir kritis peserta didik.
Abstract
Analysis of the needs of teachers and students states that learning required teaching materials that utilized multimedia as a learning medium that could be accessed on cellphones (laptops) and laptops. This study is aimed to develop learning media in the form of inquiry-based digital chemistry books on acid-base titration material. This type of research is a research and development study using the ADDIE model. The subjects in this study were chemistry teachers and students of class XI Mipa 1 in SMA Plus $N 2$ Banyuasin III. The instruments used to collect data were in the form of questionnaires, interviews, and daily logs. From the results of media validation, material validation and learning design validation state that this digital chemistry book is suitable for use in acid-base titration material. The results of the assessment of two chemistry teachers on digital books were stated to be very good with the kappa test obtained a value of 0.814. In the one-on-one trial, it was $86.67 \%$ feasibility, and in the small-group trial it was 95\%. Chemistry digital books on inquiry- based acid-base titration material are appropriate for use in chemistry learning and are expected to be applied in learning to improve students' 
critical thinking skills.

(C) 2020 JPK UNRI. All rights reserved

*Alamat korespondensi:

e-mail: petri161@gmail.com

No. Telp: -

\section{PENDAHULUAN}

Berdasarkan beberapa hasil penelitian terdahulu menyatakan peserta didik mengalami kusulitan belajar dalam materi kimia Titrasi Asam Basa. Berikut ini beberapa kesulitan yang dialami peserta didik: kesulitan dalam memilih indikator asam basa, kesulitan menuliskan persamaan reaksi, menyetarakan reaksi sampai menentukan valensi asam basa, kesulitan menetukan jenis titrasi berdasarkan kurva titrasi dan kesulitan menentukan titik ekuivalen pada titrasi asam lemah dan basa kuat (Marzuki et. al., 2017)

Dengan banyaknya kesulitan dalam belajar materi Titrasi Asam Basa akibatnya hasil belajar kimia belum memuaskan. Banyak peserta didik yang belum mencapai Kriteria Ketuntasan Minimal (KKM). SMA Plus N 2 Banyuasin III adalah sekolah unggulan di kabupaten Banyuasin provinsi Sumatera Selatan. Materi Titrasi asam basa merupakan salah satu materi yang paling tidak memuaskan. Nilai ulangan harian peserta didik pada materi Titrasi asam basa adalah 67, sementara KKM kimia 75. Untuk mengatasi masalah tersebut, pembelajaran kimia terutama materi Titrasi asam basa harus diperbaiki agar hasil belajar peserta didik meningkat. Salah satu cara adalah dengan buku digital kimia untuk Titrasi asam basa harus didesain sedemikian rupa sehingga penyampaiannya dapat berlangsung dalam suasana inkuiri dan ilmiah.

Pada kenyataannya peserta didik lebih tertarik untuk berlama-lama menggunakan teknologi digital seperti laptop dan handphone. Oleh karena itu untuk menumbuhkan minat membaca peserta didik khususnya dalam pembelajaran kimia diperlukan integrasi antara konten materi pelajaran kimia dengan teknologi. Namun penyajian konten materi berbantuan teknologi dalam pembelajaran kimia tidak hanya sekedar menarik tetapi juga harus memperhatikan konsep belajar bermakna dengan berfokus pada keaktifan peserta didik serta memperhatikan bagaimana proses penanaman konsep baru selama dia belajar.

Salah satu pembelajaran yang berfokus pada peserta didik adalah pembelajaran inkuiri. Dalam pembelajaran inkuiri, peserta didik menemukan sendiri konsep baru yang dipelajarinya melalui serangkaian tahapan mulai dari discovery learning sampai pada tahap hypothetical inquiry. Namun saat ini bahan ajar yang menunjang proses pembelajaran inkuiri sangat jarang ditemukan. Sekalipun banyak bahan ajar yang berbantuan teknologi namun bahan ajar ini pada umumnya berisi konten materi pelajaran yang mungkin tidak memperhatikan pengetahuan peserta didik terhadap konsep baru yang dipelajari.

Pada penelitian yang telah dilakukan di SMAN 1 Sangatta Utara menyimpulkan bahwa perangkat pembelajaran kimia materi pokok titrasi asam basa menggunakan model pembelajaran inkuiri yang diintegrasikan dengan strategi peta konsep layak dan dapat digunakan dalam pembelajaran untuk meningkatkan hasil belajar peserta didik (Khasanah, 2016). Berdasarkan hasil penelitian kemampuan berfikir kritis peserta didik dipengaruhi bahan ajar yang dikembangkan oleh guru. Dalam bahan ajar terdapat materi yang menghubungkan pelajaran dengan kehidupan sehari-hari dan ada pertanyaan yang merangsang peserta didik berfikir kritis (Nugraha, 2013). Berdasarkan analisis kebutuhan terhadap guru menyatakan bahwa guru kimia membutuhkan bahan ajar selain buku paket untuk mencapai KD. Dari 30 peserta didik di SMA Plus N 2 Banyuasin III didapatkan data bahwa 66,67 \% peserta didik menyatakan kimia sulit dipahami, dan semua peserta didik membutuhkan multimedia yang dapat diakses dengan menggunakan HP ataupun laptop. 
Berikut ini beberapa keunggulan buku digital dalam bentuk E-PUB yang akan dikembangkan oleh peneliti: buku digital dapat memuat konten multimedia sehingga lebih menarik dan membuat pembelajaran menjadi lebih menyenangkan. Dibandingkan dengan buku cetak, buku digital dapat disebarluaskan secara lebih mudah melalui grup WA kelas. Pada era digital saat ini, guru harus mampu menjawab tantangan jaman. Revolusi industri 4.0 menuntut guru mampu menciptakan pembelajaran dengan teknologi digital dan meningkatkan kemampuan berfikir kritis peserta didiknya. Dalam penelitian kali ini dilakukan penelitian pengembangan buku digital kimia yang dapat digunakan melalui laptop dan HP dengan aplikasi E-PUB.

Beberapa penelitian pengembangan buku digital yang telah dipublikasikan seperti Restiyowati dan Sanjaya (2012) telah mengembangkan e-book interaktif kimia dan diperoleh hasil penelitian dengan nilai kelayakan isi, bahasa dan penyajian $>80 \%$ dengan kategori sangat layak. Wijayanti et. al., (2015) telah mengusulkan e-book interaktif pada materi kesetimbangan kimia berbasis representasi kimia. Peneliti yang lain, Nur'aini et. al., (2015) telah mengembangkan e-book interaktif asam basa berbasis representasi kimia dalam materi asam basa. Febriani et al., (2019) telah melaporkan media pembelajaran interaktif berbasis autoplay media studi pada materi kepolaran senyawa dan bentuk molekul. Huda et al., (2015) telah telah menghasilkan buku digital interaktif (e-book) pada meteri termokimia berbasis representasi kimia.

Penelitian ini bertujuan untuk mengembangkan buku digital kimia pada materi asam basa berbasis inkuri. Penelitian ini mencakupi pengujian buku digital kimia meliputi ujicoba praktisi sebagai pengguna, ujicoba satu-satu dan ujicoba skala kecil. Penelitian ini diharapkan nanti dapat diterapkan dalam pembelajaran kimia untuk meningkatkan kemampuan berpikir kritis peserta didik.

\section{METODE PENELITIAN}

Jenis penelitian ini adalah penelitian pengembangan. Produk yang dikembangkan berupa buku digital kimia. Kerangka pengembangan yang digunakan dalam pengembangan buku digital dalam pembelajaran Kimia materi Titrasi asam basa yaitu kerangka pengembangan ADDIE yang terdiri dari lima tahap yaitu 1) Analisis 2) Desain, 3) Development, 4) Implementasi, 5) Evaluasi. Adapun alasan penulis memilih ADDIE karena diawali dengan analisis sebagai dasar untuk melakukan pengembangan sehingga diasumsikan produk yang dikembangkan lebih tepat menjawab kebutuhan pemecahan masalah pembelajaran (Rusdi, 2018).

Metode pengembangan buku digital kimia berasis inkuiri untuk meningkatkan kemampuan berfikir kritis peserta didik pada materi titrasi asam basa yang dikembangkan menggunakan model pengembangan ADDIE (Analisis, Desain, Pengembangan, Implementasi dan Evaluasi). Tahap Analisis disederhanakan menjadi 3 kegiatan, yaitu analisis kebutuhan guru dan peserta didik, analisis teknologi pendidikan dan analisis kurikulum. Pada tahap Desain merancang desain awal buku digital kimia dimulai dari menentukan tim pengembang, menentukan jadwal pengembangan, menentukan struktur materi, spesifikasi media yang dikembangkan, membuat flowchart dan story board. Pada tahap pengembangan produk dimulai dari mengumpulkan teks, materi video serta gambar, kemudian pengembangan produk menggunakan program E-PUB, kemudian validasi produk kepada tiga ahli yaitu ahli media, desain dan materi pembelajaran, kemudian mendapatkan produk yang layak diujicobakan. Tahap implementasi dimulai dari ujicoba produk kepada dua guru kimia untuk mendapatkan penilaian terhadap produk, setelah itu diujicobakan pada 6 orang peserta didik, dari tanggapan peserta didik dilakukan kembali analisis hasil ujicoba perorangan(satu-satu). Selanjutnya dilakukan implementasi media pada kelompok kecil dengan 9 peserta kelas XI MIPA, untuk melihat seberapa besar efektivitas media dalam meningkatkan berfikir kritis peserta didik. 


\section{HASIL DAN PEMBAHASAN}

Hasil pengembangan dari penelitian ini adalah berupa (1) sebuah buku digital kimia materi titrasi asam basa berbasis inkuiri untuk meningkatkan kemampuan berfikir kritis peserta didik materi titrasi asam basa, (2) penilaian media, desain dan materi pembelajaran pada pengembangan buku digital kimia materi titrasi asam basa berbasis inkuiri dilakukan oleh ahli desain, ahli media serta ahli materi dengan menggunakan angket, (3) penilaian guru (praktisi) terhadap buku digital kimia materi titrasi asam basa berbasis inkuiri dilakukan dengan penyebaran angket, dan (4) penilaian seluruh responden peserta didik yang terdiri dari uji coba perorangan (satu-satu) dan uji coba kelompok kecil terhadap buku digital kimia materi titrasi asam basa berbasis inkuiri yang telah dibuat dengan menyebarkan angket. Responden terdiri dari 6 orang peserta didik kelas XI MIPA di SMA Plus N 2 Banyuasin III sebagai subjek uji coba perorangan (satu-satu). Pada ujicoba kelompok kecil melibatkan 9 orang peserta didik kelas XI MIPA serta menggunakan 2 orang guru kimia untuk memberikan penilaian terhadap buku digital kimia materi titrasi asam basa berbasis inkuiri.

\subsection{Ujicoba Praktisi}

Penilaian dari guru kimia dilakukan untuk melihat media yang sudah dikatakan layak oleh tim validator sesuai atau tidak dengan pengguna. Disini guru kimia yang nantinya menggunakan media ini dalam proses mengajar selanjutnya harus memeriksa kembali produk yang telah dibuat agar buku digital kimia yang dibuat tepat guna saat digunakan oleh pengguna.

Penilian guru terhadap Buku digital kimia yang dikembangkan melibatkan dua guru kimia. Guru tersebut diminta memberi penilaian terhadap Buku digital kimia dengan cara penyebaran angket. Dari hasil uji kappa terhadap penilaian 2 guru kimia terhadap penilaian buku digital kimia didapatkan nilai 0,814 artinya sangat baik. Uji Kappa digunakan untuk menilai kesepakatan antara 2 guru kimia dalam menilai buku digital kimia.

\subsection{Ujicoba Satu-Satu}

Uji coba satu-satu dilakukan kepada 6 orang peserta didik lalu meminta saran mereka tentang produk yang dikembangkan. Jika terdapat komentar dan saran perbaikan maka pengembang wajib merevisi terlebih dahulu, sebelum melanjutkan ke uji coba kelompok kecil. Uji coba satu-satu sudah dilaksanakan di SMA Plus N 2 Banyuasin III pada tanggal 19 Desember 2019 dengan peserta didik kelas XI MIPA sebanyak 6 orang.

Berdasarkan data hasil respon peserta didik terhadap buku digital kimia, menunjukkan bahwa media pembelajaran buku digital kimia berbasis inkuiri pada materi titrasi asam basa dikategorikan "Sangat Layak" dengan perhitungan pada persamaan 1:

$$
P=\frac{Q}{R} \times 100 \%
$$

Dimana, $\mathrm{P}$ merupakan nilai persentase yang diperoleh, $\mathrm{Q}$ adalah jumlah skor atau nilai yang diperoleh dan $\mathrm{R}$ adalah jumlah nilai maksimum. Berdasarkan pengujian satu-satu diperoleh nilai sebesar Q sebesar 234 dan nilai R sebesar 270. Pada uji coba ini diperoleh nilai kelayakan sebesar $86,67 \%$ dengan predikat sangat baik.

\subsection{Ujicoba Kelompok Kecil}

Uji coba kelompok kecil dilakukan pada tanggal 20 Desember 2019 bersama 9 orang peserta didik kelas XII MIPA yang dipilih dengan metode purposive sampling. Uji coba kelompok kecil ini dilakukan secara bertahap dimulai dari penyajian buku digital kimia untuk memahami materi hingga berlanjut pada sesi praktikum titrasi asam basa. Dalam uji coba kelompok kecil ini terlihat jelas 
antusia peserta didik. Motivasi belajar yang tinggi dan kompetensi yang bertambah didapatkan peserta didik dari penggunaan buku digital. Saat sesi praktikum titrasi asam basa di laboratorium kimia disini mayoritas peserta didik sudah memahami cara melakukan titrasi asam basa dan perhitungannya. Dari 9 orang peserta didik yang mengikuti praktikum memberikan respon positif dan menyatakan bahwa materi titrasi asam basa menjadi lebih mudah dipahami dengan menggunakan buku digital kimia. Berdasarkan data hasil perhitungan pada uji coba kelompok kecil buku digital kimia pada meteri titrasi asam basa berbasis inkuiri diperoleh nilai sebesar $95 \%$ dengan kategori sangat baik.

Secara umumnya, berdasarkan pengujian praktisi, ujicoba satu-satu dan ujicoba kelompok kecil, buku digital kimia pada materi titrasi asam basa layak digunakan untuk pembelajaran. Buku digital yang dikembangkan ini, diharapkan dapat untuk diterapkan dalam pembelajaran kimia pada materi titrasi asam basa untuk meningkatkan kemampuan berpikir kritis peserta didik.

\section{KESIMPULAN}

Produk diujicobakan kepada dua guru mata pelajaran kimia untuk meminta penilaian terhadap produk yang dikembangkan hasil penilaian dua guru dengan uji kappa didapatkan nilai 0,814 artinya kesepakatan sangat baik. Kelayakan produk menurut praktisi (guru kimia) sebesar 91,8\% menunjukkan sangat layak digunakan dalam pembelajaran.

Penilaian respons peserta didik didapatkan melalui uji coba peserta didik yaitu uji coba satusatu mendapatkan nilai kelayakan sebesar $86,67 \%$ dan uji coba kelompok kecil kelayakan sebesar 95\% artinya menunjukkan bahwa buku digital kimia layak digunakan dalam pembelajaran kimia di sekolah.

\section{DAFTAR PUSTAKA}

Febriani, P., Holiwarni, B., Yasmi, E. 2019. Pengembangan media pembelajaran interaktif berbasis autoplay media studio 8.5 pada subpokok materi kepolaran senyawa dan bentuk molekul untuk kelas X SMA/MA. Jurnal Pendidikan Kimia Universitas Riau. 4(1): 36-47

Huda, T.A., Fadiawati, N., Tania, L. 2015. Pengembangan e-book interaktif pada materi termokimia berbasis representasi kimia. Jurnal Pendidikan dan Pembelajaran Kimia. 4(2); 530-542.

Khasanah, M. N., Suyatno. 2016. Desain Perangkat Pembelajaran Kimia Pokok Materi Titrasi Asam Basa Dengan Model Pembelajaran Inkuiri Yang Diintegrasikan Dengan Strategi Peta Konsep Untuk Meningkatkan Hasil Belajar Peserta didik. Pendidikan Sains Pascasarjana Universitas Negeri Surabaya, 6: 1184-1195.

Marzuki, H.R.T.A. 2017. Analisis Kesulitan Pemahaman Konsep Pada Materi Titrasi Asam Basa Peserta didik SMA. Jurnal Pendidikan Kimia. 1(1):22-27.

Nugraha, D.A. 2013. Pengembangan Bahan Ajar Reaksi Redoks Bervisi SETS berorientasi Konstruktivistik, Unnes semarang. Journal of Innovative Science Education. 2(1): 29-34.

Nur'aini, D., Fadiawati, N. Tania, L.2015. Pengembangan e-book interaktif asam basa berbasis representasi kimia. Jurnal Pendidikan dan Pembelajaran Kimia. 4 (2); 517-529

Restiyowati I., Sanjaya, I.G.M. 2012. pengembangan e-book interaktif pada materi kimia semester genap Kelas XI SMA. Unesa Journal of Chemical Education. 1(1); 130-135

Rusdi, M. 2018. Penelitian Desain dan Pengembangan Kependidikan: Konsep, Prosedur, dan Sintesis Pengetahuan Baru.Rajawali Press. Jakarta.

Wijayanti, S., Fadiawati, N., Tania, L. 2015. Pengembangan e-book interaktif kesetimbangan kimia berbasis representasi kimia. Jurnal Pendidikan dan Pembelajaran Kimia. 4(2): 481-492 